\title{
Model Bercerita untuk Peningkatan Keterampilan Menyimak dan Berbicara Anak Usia 5-6 Tahun
}

\author{
Riwayati Zein $^{\varpi_{1}}$, Vivi Puspita ${ }^{2}$ \\ Pendidikan Guru Pendidikan Anak Usia Dini, Sekolah Tinggi Keguruan dan Ilmu \\ Pendidikan Adzkia \\ DOI: $10.31004 /$ obsesi.v5i2.581
}

\begin{abstract}
Abstrak
Tujuan penelitian ini adalah menghasilkan suatu model pembelajaran bercerita tematik perkembangan bahasa (BTPB) yang dapat peningkatkan keterampilan bahasa anak. Khususnya keterampilan menyimak dan berbicara. Pengembangan ini menggunakan model ADDIE (analysis, desaign, development, implementation dan evaluation) dengan empat tahapan penelitian yaitu 1) Tahap Need Analyze; 2) tahap perancangan; 3) tahap pengembangan 4) tahap implimentasi. Validasi prodak dilakukan oleh ahli bahasa, pakar AUD dengan mengunak angket, lembar instrument observasi dan dokumentasi. Sampel penelitian yaitu TK Adabiah dan TK Adzkia. Responden penelitian terdiri dari 8 orang guru. Berdasarkan hasil validasi ahli diperoleh penilaian dari aspek kelayakan, kebahasaan, kegrafikan dan azas manfaat dengan kriteria sangat valid. Hasil uji coba penelitian penggunaan model BTPB terdapat peningkatan keterampilan menyimak dan berbicara pada kelas eksperimen dari pada anak kelas control, dengan demikian model PTPB dinyatakan layak untuk digunakan dalam pembelajaran di AUD.
\end{abstract}

Kata Kunci: keterampilan bahasa; menyimak; berbicara; model pembelajaran btpb

\begin{abstract}
The purpose of this research is to produce a learning model for thematic language development (BTPB) which can improve children's language skills. Especially listening and speaking skills. This development uses the ADDIE model (analysis, design, development, implementation and evaluation) with four stages of research, namely 1) Need Analyze Stage; 2 ) the design stage; 3) development stage 4) implementation stage. Product validation is carried out by linguists, AUD experts by using questionnaires, observation instrument sheets and documentation. The research sample was TK Adabiah and TK Adzkia. The research respondents consisted of 8 teachers. Based on the results of expert validation, an assessment was obtained from the aspects of feasibility, language, graphics and the principles of benefit with very valid criteria. The results of the research trial using the BTPB model showed an increase in listening and speaking skills in the experimental class than in control class children, thus the PTPB model was declared suitable for use in learning in AUD.
\end{abstract}

Keywords: language skills; listening; speaking; btpb learning model.

Copyright (c) 2020 Riwayati Zein, Vivi Puspita

$\triangle$ Corresponding author:

Email Address : riwayatizein@yahoo.com ( Padang, Indonesia )

Received 4 June 2020, Accepted 27 August 2020, Published 23 Oktober 2020 


\section{PENDAHULUAN}

Keterampilan berbahasa merupakan kemampuan dalam menggunakan pengetahuan kebahasaan dalam berkomuniakasi. Keterampilan berbahasa menurut (Zuhdi, 1999) yaitu menyimak, berbicara, membaca dan menulis. Keempatnya saling berhubungan erat untuk meningkatkan keterampilan lainnya, empat keterampilan berbahasa tersebut di peroleh manusia seiring pertumbuhannya secara berurutan. Pada anak usia dini aspek menyimak dan berbicara paling dominan digunakan karena anak belum bisa tulis-baca. Pada kegiatan bercerita anak berupaya menyimak/mendengarkan cerita gurunya. Selanjutnya anak akan kembali dengan bahasanya sendiri.

Pemerolehan keterampilan berbahasa pada anak menurut (Sonawat \& Francis, 2007) adalah dengan menginterpretasikan apa yang mereka lihat, mengenal, memahami dan menuturkan bahasa dari apa yang didengar dari lingkungan kehidupannya. Penting bagi anak untuk dapat mengungkapkan apa yang mereka lihat, mereka pahami dengan cara menuturkan bahasa. dengan demikian lingkungan berkontribusi terhadap penguasaan kosakata anak.

Kemendiknas (2010a) mengungkapkan bahwa perkembangan bahasa merupakan salah satu dari bidang pengembangan dasar bagi anak usia 5-6 tahun di TK. Perkembangan bahasa berkaitan dengan perkembangan kognitif anak. Otak manusia bersifat hologram yang dapat mencatat, menyerap, menyimpan, memproduksi dan merekonstruksi informasi yang diterimanya. Kemampuan otak dipengaruhi oleh stimulasi yang di terimanya pada awal tahun kehidupan anak dan mulai berkembang pada tahun kedua untuk mengenal dan menggunakan simbol-simbol. Salah satu kegiatan yang dapat dilakukan adalah dengan bercerita.

Bercerita didefinisikan sebagai penghubung sebuah cerita kepada satu atau lebih pendengar melalui suara dan gerakan (Rosdiana et al., 2011). Dengan demikian bercerita adalah seni menggunakan bahasa, vokalisasi, dan atau gerakan fisik dan isyarat untuk mengungkapkan unsur-unsur dan gambaran dari sebuah cerita kepada sesuatu yang spesifik, kehidupan kepada anak. Dengan bercerita akan membantu kemampuan bahasa anak melalui kegiatan mendengarkan untuk selanjutnya menuturkan kembali dengan bahasanya. Kegiatan terebut tidak terlepas dari aktivitas yang dilakukan sehari-hari.

Kegiatan bercerita memiliki beberapa manfaat bagi anak, seperti memperkaya kosakata, memperbaiki kalimat serta melatih keberanian anak dalam berkomunikasi. Bercerita dapat meningkatkan aspek nilia agama dan moral anak (Kusnilawati et al., 2018), menambah kosa kata anak (Andriyani et al., 2018), dan meningkatkan kemampuan daya serap dan daya piker anak (Taja et al., 2019). Hal ini sesuai dengan penelitian yang dilakukan (Darmila et al., 2018). Dengan mengajak anak untuk mendengarkan cerita memberikan kontubusi terhadap kemampuan anak dalam berbicara. Selanjutnya dalam Jurnal pendidikan dan pengembangan yang ditulis oleh Agam (2012) tentang peningkatan Bahasa anak melalui bermain peran di Taman kanak-kanak, Hasil penelitian memberikan informasi bahwa berkembangan Bahasa anak belum berkembang. Hal ini merupakan dua hal yang bertolak belakang mengingat, mengingat pentingnya manfaat bercerita bagi kemampuan bahasa anak. Sedangkan Anggraeni et al. (2019) mendapati metode bercerita menggunakan media boneka tangan dan big book memiliki peranan untuk meningkatkan kemampuan berbicara pada anak usia 7-8 tahun.

Fauziddin (2017) memaparkan penyebab rendahnya kemampuan bahasa anak disebabkan karena dalam proses pembelajaran anak kurang percaya diri dan anak tidak bisa melakukan kegiatan yang menarik dalam belajar. Oleh karena itu perlu di rancang kegiatankegiatan yang dapat menumbuh kembangkan kepercayaan dirinya sendiri, kreatifitas dalam proses pembelajaran. Permaslahan yang sering terjadi, siswa terkadang tidak dapat memulai suatu percakapan, seperti halnya memilih kosa kata dalam berbicara atau merangkai kalimat kalimat yang akan dilontarkan. 
Model Bercerita Untuk Peningkatan Keterampilan Menyimak dan Berbicara Anak Usia 5-6 Tahun

DOI: $10.31004 /$ obsesi.v5i2.581

Fakta lapangan pada tujuh TK di kota Padang menemukan beberapa permasalahan pada anak usia 5-6 tahun. Pembelajaran lebih terkonsentrasi pada pengalaman membacamenulis, kegiatan mengambar dan mewarnai, sehingga aspek menyimak dan berbicara sering terabaikan. Kegiatan membaca dan menkis akan lebih bermakna jika didahului dengan kegiatan bercerita. Pengembangan aspek bahasa yang utuh diawali dengan memperkuat sensori motor terkait oran-organ pendengaran dan berbicara. Jika kedua organ tersebut telah kuat diharapkan potensi yang lebih tinggi akan memudahkan anak untuk mengembangkan bahasanya khususnya menyimak dan berbicara. Hasil wawancara dengan beberapa guru TK pada studi awal diperoleh beberapa informasi sebagai berikut: (1) secara administrasi bercerita belum dicantumkan dalam RPPH (rencana pelaksanaan pembelajaran harian) namun pada prakteknya guru pernah/sering melakukan aktifitas bercerita, (2) kegiatan bercerita dilakukan pada hari-hari tertentu contohnya terkait perjalanan hidup para nabi, (3) pelaksanaan kegiatan bercerita dilakukan tanpa persiapan yang matang, seperti menyesuaikannya dengan topik, menggali makna menentukan metode dan teknik bercerita, serta mempersiapkan media yang sesuai dengan cerita.

Permasalahan di atas menjelaskan bahwa kegiatan menyimak dan berbicara masih terabaikan. Padahal masa usia 5-6 tahun merupakan masa peka, tujuannya adalah agar anak mampu mengungkapkan pikiran melalui bahasa yang sederhana secara lisan dan mampu berkomunikasi sesuai dengan karakteristik perkembangan bahasa anak. Dengan demikian tujuannya adalah agar anak mampu mengekspresikan dirinya dengan berbicara, menambah kosa kata dan menyusun kalimat secara lancar dan jelas. Berdasarkan hasil obesevasi awaldiperoleh hasil belajar perkembangan bahasa anak sebesar $34,26 \%$ dengan demikian perkembangan bahasa anak masih berada pada kriteria rendah.

Kondisi pelaksanaan kegiatan bercerita yang dilakukan guru dapat dicermati berdasarkan uraian serta hasil survey dan wawancara. Maka identifikasi permasalahan utama adalah belum adanya perangkat pembelajaran yang terintegarasi antara aktifitas bercerita dengan aspek perkembangan bahasa anak khususnya menyimak dan berbicara. Perangkat pembelajaran ini diharpakan dapat menjadi panduan guru dalam melaksanakan pembelajaran. perangkat pembelajaran yang dimaksud adalah kegiatan pembelajaran melalui kegiatan bercerita.

Bercerita menurut (Suharsiwi, 2000) merupakan cara mengutarakan suatu peristiwa atau kejadian yang di dalamnya terlibat beberapa tokoh. Hal sama didukung (Moeslichatoen, 2006) yaitu pemberian pengajaran secara lisan kepada anak dengan membaca cerita. Kedua pendapat tersebut menyatakan bercerita pemberian pengalaman secara lisan lewat peran tokoh cerita. Kegiatan bercerita pada penelitian ini mewakili interaksisosial yang ada dilingkungan sekitar serta pesan-pesan moral. Pesan moral dari makna cerita dapat menjadi pembelajaran bagi siswa untuk dapat bertindak dengan baik dan benar dalam kehidupan.

Bercerita pada kegiatan belajar anak usia dini menurut (Elena, 1996) merupakan upaya menstimulasi pengembangan ketrampilan berbahasa secara lisan, berfikir logis, dan memaknai nilai-nilai yang terdapat dalam cerita. Vygotsky menyarankan delapan jenis permainanbagistimulasiperkembangananakusiadini, salah satunya adalah bercerita. (Solehuddin, 2010) menjelaskan bahwa bercerita merupakan stimulasi yang dapat melibatka anak secara mental. Dengan demikian bercerita dapat digunakan sebagai suatu metode pembelajaran yang membantu guru dalam melibatkan anak secara mental.

Penelitian yang dilakukan oleh (Kurniaman \& Huda, 2018) di kelas awal sekolah dengan strategi bercerita dapat meningkatkan keterampilan menyimak anak serta memberikan sejumlah pengetahuan sosial, nilai-nilai moral, dan keagamaan kepada anak untuk bisa diterapkan dalam kehidupan sehari-hari, dan dapat mengembangkan kemampuan kognitif, afektif maupun psikomotor yang dimiliki oleh anak, serta dapat melatih daya serap anak, melatih daya piker anak dan melatih daya konsentrasi anak selain itu anak juga cenderung lebih menyukai pembelajaran yang berbasis cerita. 
Dewi \& Wiyasa (2018) melakukan penelitian di anak usia 5-6 tahun dengan menggunakan metode bercerita menggunakan wayang. Hasil penelitian menunjukkan kemampuan anak untuk mengarahkan pandangannya kepada guru, anak tidak terpengaruh pada temannya yang mengajak ngobrol, anak dapat menjawab pertanyaan guru pada akhir pelajaran. Dengan demikian metode bercerita dapat memberikan perbaikan terhadap perkembangan bahasa anak khususnya menyimak dan berbicara. Penelitian pengembangan model bercerita merupakan salah satu upaya untuk merevisi kegiatan bercerita yang dilakukan guru dengan demikian perlu dirancang suatu model pembelajaran yang dapat menyelesaikan permasalah tersebut yaitu Bercerita Tematik Perkembangan Bahasa (BTPB). Sepertihalnya hasil penelitian pada anak usia 3-5 tahun, dengan bercerita dapat memberikan pengaruh terhadap perkembangan Bahasa anak. Selanjutnya penelitian Agam et al. (2014) menunjukkan hasil bahwa dengan bercerita dapat melatih kemampuan berempati anak. Hasriana Desti (2014) pada penelitiannya menunjukkan bahwa dengan bercerita mempu meningkatkan kedisiplinan anak. Selanjutnya hasil penelitian Darmila et al. (2018) dapat meningkatkan kemampuan kosa kata dan berkomunikasi siswa.

\section{METODOLOGI}

Penelitian model bercerita ini merupakan penelitian dengan pengembangan (research $\mathcal{E}$ Develepment). Pengembangan diartikan mendaya gunakan sesuatu yang sudah ada sehingga lebih berdayaguna. Prosedur penelitian dan pengembangan model merupakan langkahlangkah yang sitematis untuk mengambangakan proses dan aktivitas penelitian. Aktivitas mendeskripsikan penelitian dan pengembangan menurut (Kleain, 2007) denganp rosedur ADDIE. Karakteristik pengembangan model ADDIE dasar-dasar bersifat umum, sistematis dan kerangka kerjanya bertahap.

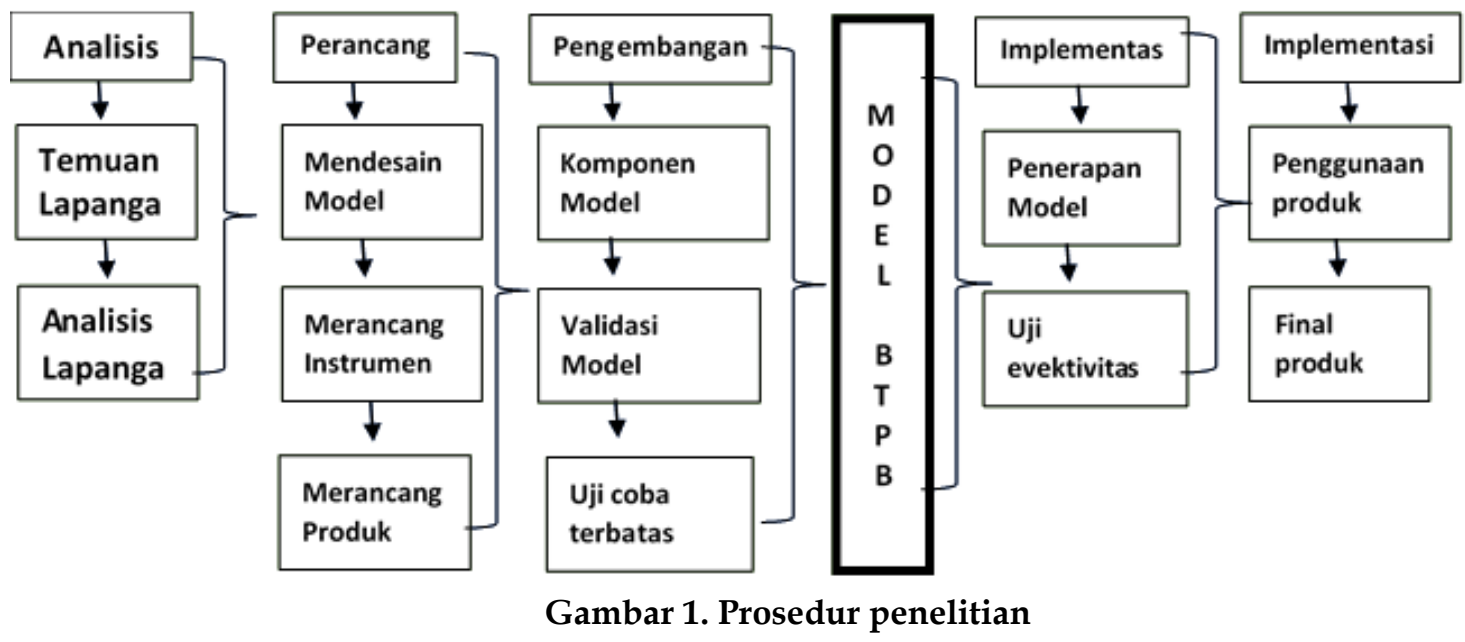

Prosedur penelitian (gambar 1) diawali dengan analisis kondisi lapangan melalui wawancara, angket, dan observasi sehingga diperoleh temuan lapangan (need analysis). Analisis awal merupakan patokan dari upaya perancangan dan pengembangan draf model secara menyeluruh dan model sebagai landasan pengembangan. Pada tahap ini dilakukan wawancara dan penyebaran angket kepada responden, hasil angket selanjutnya mengikuti kriteria sebagai berikut.

Tabel 2. kriteria taraf keberhasilan

\begin{tabular}{cc}
\hline $80 \%-100 \%$ & sangat baik \\
$70 \%-79 \%$ & baik \\
$60 \%-69 \%$ & cukup \\
$<59 \%$ & kurang \\
\hline
\end{tabular}


Data tahap pengembangan dilakukan dengan melakukan validasi ahli yang meliputi validasi produk, praktikalitas produk serta evaluasi produk sehingga menghasi lkan produk yang valid dan praktis. Produk yang telah valid dan praktis selanjutnya dilakukan uji coba model secara terbatas dengan menggunakan metode ekperimen khususnya pada aspek menyimak dan berbicara. Sumber uji coba adalah TK Adabiah, dan TK Adzkia, Kedua sekolah ini diambil karena telah memiliki kesamaan kritieria dan cocok untuk dilakukan uji coba. Subjek penelitian berjumlah 24 AUD.

Teknik analisis data diperlukan untuk memenuhi prosedur selanjutnya dalam proses pengembangan model sesuai rancangan penelitian. Data penelitian pengembangan ini terdiri dari tahap ananalisis dan pengembangan. Analisis data disesuaikan dengan jenis data sebagai berikut.

Data tahap analisis merupakan data kualitatif yang diperoleh dari wawancara, angket dan observasi. Yang dianalisis dengan analisis flow model berupa reduksi data, penyajian data, dan penarikan kesimpulan. Kedua data tahap pengembangan merupakan data kuantitatif yang diperoleh dari tim validator untuk menilai kelayakan produk. Uji validitas mengikuti kriteria sebagai berikut.

Tabel 1. Kriteria uji validitas produk menurut (Purwanto, 2010)

\begin{tabular}{|c|c|c|}
\hline Aspek & Kriteria ketercapaian & kategori \\
\hline & $<0.80$ & Tidak valid \\
\hline \multirow[t]{3}{*}{ Validitas } & $0.81-1.60$ & Kurang valid \\
\hline & $1.61-2.40$ & Cukup valid \\
\hline & $2.41-3.20$ & Valid \\
\hline \multirow[t]{5}{*}{ Praktikalitas } & $<20 \%$ & Tidak praktis \\
\hline & $21-40 \%$ & Kurang praktis \\
\hline & $41-60 \%$ & Cukup praktis \\
\hline & $61-80 \%$ & Praktis \\
\hline & $81-100 \%$ & Sangat praktis \\
\hline
\end{tabular}

\section{HASIL DAN PEMBAHASAN}

\section{Analisis lapangan}

Hasil pengidentifikasian temuan lapangan diarahkan pada aspek berikut a) hasil analis siswa ditemukan bahwa permasalahan bercerita guru belum memiliki perangkat pembelajaran khusus untuk perkembangan bahasa yang terinteraksi dengan bercerita. (b) hasil analisis anak menemukan bahwa kondisi pembelajaran bercerita untuk perkembangan Bahasa anak belum terspesialisasi. Hal ini juga diketahui dari hasil observasi bahwa hasil perkembangan belajar anak rendah. c) hasil analisis konsep menemukan bahwa konsepkonsep yang berkaitan dengan kajian dan focus penelitian perlu dipahami oleh guru. Hal tersebut sesuai dengan pendapat (J.L, McBrien \& R.S, 1997) bahwa konstruktivis memerupakan suatu pendekatan pembelajaran yang membahas bagaimana seseorang belajar berdasarkan pengalaman lama, struktur kognitif anak menyusun dan membangun pengetahuan baru. Hasil analisis tujuan pembelajaran menemukan tujuan pembelajaran belum sesuai dengan aspek perkembangan Bahasa anak. e) hasil analisis tugas menemukan bahwa karakteristik tugas anak belum sesuai dengan tujuan perkembangan Bahasa anak yang terintegarasi dengan kegiatan bercerita. Hal lain juga belum ditemukan adanya evaluasi individual yang digunakan guru untuk mendeteksi perkembangan belajar anak.

Hasil pengidentifikasian temuan lapangan di atas didukung oleh hasil wawancara, angket dan observasi. Hasil wawancara dengan delapan responden dideskripsikan bahwa perencanaan pembelajaran secara umum yang dilakukan guru sudah cukup baik. Guru belum memiliki perencanaan yang khusus untuk perkembangan bahasa yang terintegrasi dengan kegiatan bercerita. Secara umum kegiatan bercerita sudah tidak asing bagi guru karena sering dilakukan, kegiatan bercerita cenderung bersifat insidensial karena tanpa persiapan khusus. 
Hal ini terlihat pada belum termuatnya kegiatan bercerita pada RPH yang dirancang oleh guru.

Pelaksanaan bercerita belum terintegrasi dengan indikator perkembangan Bahasa anak usia 5-6 tahun di TK. Adapun yang menjadi Indikator capaian perkembangan bahasa anak usia 5-6 tahun diantaranya adalah 1) menjawaab pertanyaan yang kompleks, 2) mengkomunikasikan secara lisan, 2) memiliki perbendaharaan kata untuk mengekspresikan ide pada orang lain, 3) menyusun kalimat sederhana, melanjutkan cerita, 4) mengerti beberapa perintah secara bersamaan, 5) mengulang kalimat yang lebih kompleks. Dengan kegiatan bercerita akan memudahkan siswa dalam mencapai indikator perkembangan. Materi cerita menggunakan teks cerita pada majalah anak. Evaluasi individual untuk perkembangan bahasa dan bercerita belum dimiliki guru. Evaluasi setelah pembelajaran merupakan rangkaian proses pembelajaran, dengan melakukan evaluasi secara individual guru dapat dengan mudah menentukan perlakuan atau perbaikan terhada pembelajaran selajutnya. Observasi terhadap proses pembelajaran dilakukan untuk mengetahui hasil perkembangan belajar anak. Hasil observasi perkembangan Bahasa diketahui sebesar 34.26\% kategorinya rendah.

Temuan angket terhadap analisis kebutuhan dapat disimpulkan sebagi berikut. Hasil temuan angket perencanaan pada umumnya berkisar di bawah $60 \%$, temuan ini disimpulkan bahwa secara umum perencanaan guru cukup baik. (Verika, 2015) menjelaskan bahwa proses pembelajaran yang diawali perencanaan yang sangat matang mempengaruhi keberhasilan suatu proses pembelajaran. Temuan lapangan menunjukkan bahwa kurangnya pemahaman guru dalam merancang aktivitas pembelajaran yang memiliki muatan keterampilan berbahasa.

Hasil temuan angket pelaksanaan umumnya berkisar di bawah $60 \%$. Temuan ini disimpulkan pada umumnya pelaksanaan bercerita yang dilakukan guru cukup baik. evaluasi yag dilakukan oleh guru disesuaikan dengan pedoman penilaian, dengan demikian temuan angket hasil evaluasi secara umum cukup baik. Hasil observasi menunjukkan perbedaan kegiatan yang dilakukan guru dengan perancangan yang telah dibuat sebelumnya. Contohnya pada perencanaan tidak dicantumkan penggunaan cerita, namun pada pelaksanaannya guru mulai bercerita di depan kelas. Kegiatan bercerita yang disampaikan guru kurang manarik minat siswa, untuk itu guru perlu dibekali dengan keterampilan bercerita.

Bercerita yang dilakukan guru dalam peleksanaan pembelajaran memiliki kekuatan terkait struktur model yaitu (1) sintak, langkah-langkah pembelajaran yang dilakukan guru, mengatur duduk anak setelah itu mengajak anak berdoa, menyebutkan judul bercerita. 2) system sosial, adanya interaksi guru dan anak, mengucapkan dan menjawab salam, menyapa anak, merespon anak. 3) prinsip reaksi yaitu pandangan dan respon guru terhada panak. Implikasi dalam proses pembelajaran bahwa guru membiasakan berdoa, memotivasi anak, memberi penguatan 4) system pendukung yang digunakan guru, menggunakan teks bercerita dari majalah anak-anak. 5) efek model, anak mengenal judul cerita, nama tokoh cerita, makna cerita.

Kelemahan model cerita guru yang pertama adalah pertemuan : 1) belum ada rencana kegiatan mingguan, rencana harian dan silabus pembelajaran yang khusus untuk perkembangan bahasa yang terintegrasi dengan kegiatan bercerita. 2) kegiatan bercerita sering dilaksnaakan guru namun cenderung bersifat insidensial. Kelemahan kedua adalah pada pelaksanaan, yaitu 1) pelaksanaan dilakukan dengan persiapan seadanya, 2) pelaksanaan bercerita dilakukan untuk pengkondisian kelas, 3) belum ada lembar pendamping kegiatan belajar anak secara individu untuk aspek perkembanngan bahasa. Kelemahan ketiga adalah aspek evaluasi: yaitu 1) kegiatan tanya jawab yang belum maksimal.

2) belum adanya evaluasi individual yang terintegrasi antar perkembangan bahawa. 
Model Bercerita Untuk Peningkatan Keterampilan Menyimak dan Berbicara Anak Usia 5-6 Tahun

DOI: $10.31004 /$ obsesi.v5i2.581

Berdasarkan hasil temuan tahap analisis maka secara spesifik need analysis pertemuan dan pengembangan bercerita dirangkum dalam tabel 2 .

\section{Pengembangan Model BTPB}

Produk hasil penelitian merupakan model bercerita BTPB. Penjelasan hasil penelitian dan pengembangan diuraikan berdasarkan rancangan struktur Model BTPB yang terdiri dari Langkah persiapan dan struktur model. Langkah persiapan merupakan kegiatan guru merumuskan perencanaan pembelajaran. Sesuai dengan pendapat (Hartati, 2005) bahwa perencanaan pembelajaran merupakan program tertulis guna memperlancar kegiatan belajar. (Apriyanti, 2017) memaparkan Perencanaan sebagai hubungan antara apa yang ada sekarang (what is) dengan bagaimana seharusnya (what should be) yang bertalian dengan kebutuhan, penentuan tujuan, prioritas, program dan alokasi waktu. pada perancangan memerlukan kajian khusus bercerita dengan terintegrasi perkembangan Bahasa. Tujuannya agar guru menentukan capaian dan indikator perkembangan Bahasa anak.

Perkembangan bahasa dengan bercerita dimulai dengan menentukan cerita sesuai dengan tema yang akan dipelajari. Pemilihan cerita anak harus memenuhi kriteria (Arlyanti \& Apriliya, 2018) menjelaskan langkah awal pemilihan cerita anak adalah sesuai dengan karakteristik siswa. Selanjutnya dirancang kegiatan dan teknik dalam bercerita yang akan dilakukan oleh guru.

Struktur model BTPB terdiri dari langkah pembelajaran (sintak) system sosial, prinsip reaksi, system pendukung dan efek model BTPB (gambar 2). Hal ini sesuai dengan penjelasan (Nieveen, 2009) (Bachri, 2005) bahwa suatu produk dikatakan valid jika intervensi/perlakuan yang diberikan memenuhi kebutuhan dan komponennya berdasarkan pengetahuan mutakhir dan semua komponen saling terkait.

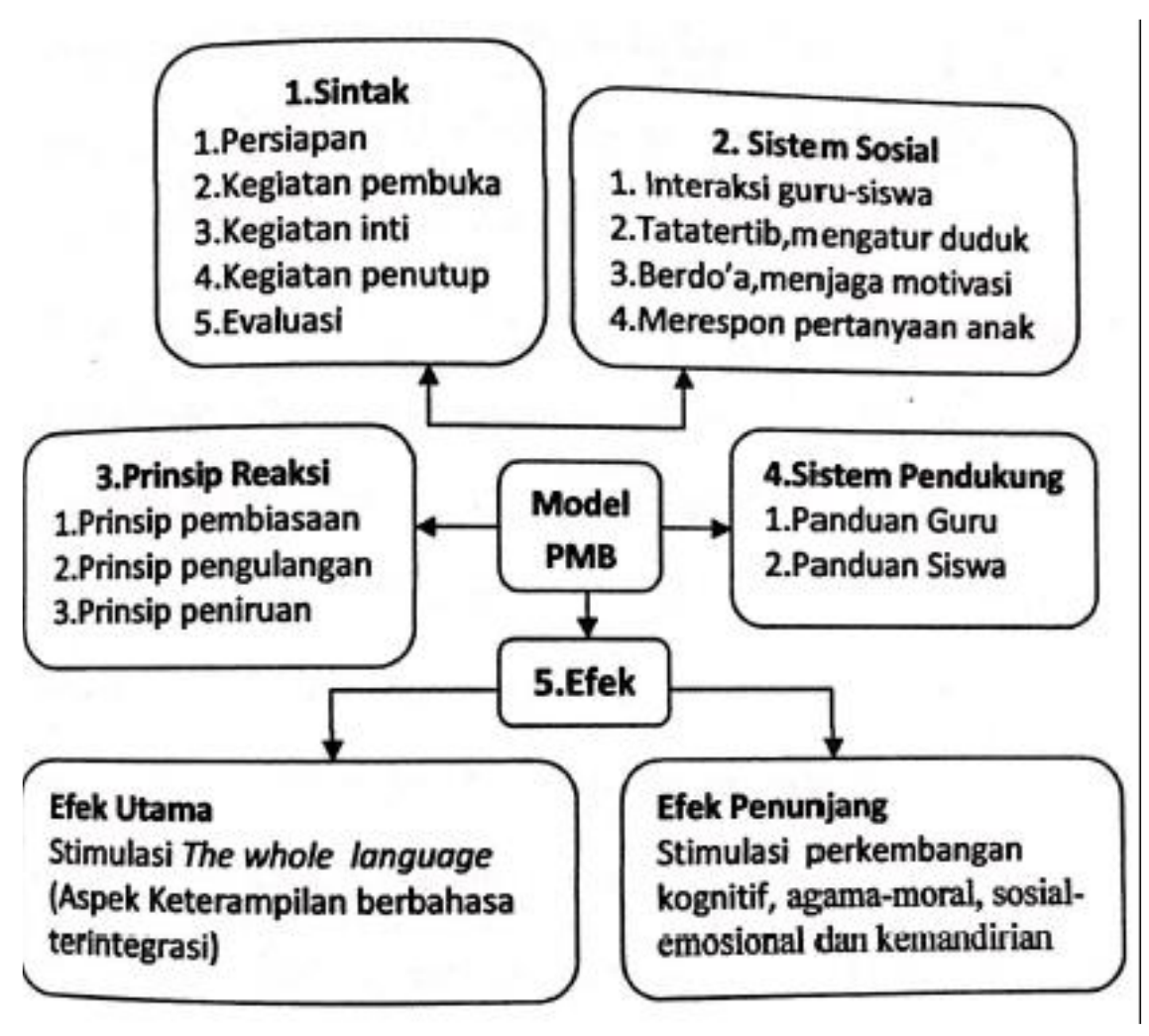

Gambar 2. Hasil pengembangan model BTPB

Validitas pengembangan produk diperoleh hasil dengan rerata sangat valid. Rinciannya dapat dilihat pada tabel 3. 
Tabel 2 rangkuman Need Analysis

\begin{tabular}{|c|c|c|c|}
\hline No & Komponen & $\begin{array}{l}\text { Kebutuhan } \\
\text { Guru }\end{array}$ & Anak \\
\hline 1 & Perencanaan & $\begin{array}{l}\text { Rencana mingguan, harian dan } \\
\text { silabus }\end{array}$ & \\
\hline 2 & Pelaksanaan & $\begin{array}{l}\text { Teks cerita sesuai tema dan tujuan } \\
\text { pembelajaran } \\
\text { PKA yang sesuai dengan } \\
\text { perkembangananak 5-6 tahun }\end{array}$ & $\begin{array}{l}\text { Teks cerita yang sesuai dengan } \\
\text { perkembangan anak usia 5-6 } \\
\text { tahun }\end{array}$ \\
\hline 3 & Evaluasi & Evaluasi individu sesuai tema & $\begin{array}{l}\text { Pendamping kerja siswa sesuai } \\
\text { tema }\end{array}$ \\
\hline
\end{tabular}

Tabel 3 hasil validasi buku model

\begin{tabular}{llll}
\hline No & Indikator ukur & Skorrerata & Kategori \\
\hline A & Kelayakanisi & 3.74 & Sangat valid \\
B & Kebahasaan & 3.56 & Sangat valid \\
C & Kegrafikan & 3.50 & Sangat valid \\
D & Azas manfaat & 3.77 & Sangat valid \\
\hline
\end{tabular}

Hasil uji coba yang dilakukan pada dua sekolah di TK Adabiah dan TK Adzkia di peroleh informasi bahwa terdapat pengaruh yang signifikan terhadap keterampilan berbicara dan menyimak anak yang menggunakan model BTPB. Hasil perhitungan dengan SPSS di dapat $t$ hitung dengan nilai sig. Sebesar 0,00. Artinya uji coba menunjukkan perbedaan kemampuan perkembangan Bahasa anak sebelum dan setelahdilakukan uji coba.

Hasil implementasi model BTPB dalampembelajarangunamengetahuiefektifitasdari model yang digunakan. Diperolehskor rata-rata sebelum uji coba 26,25 setelah uji coba 31,00. Peningkatan skor sebelum dan setelah uji coba 4,21. Koefisien korelasi 0,63 dengan nilai sig. Sebesar 0,032. Hal ini menunjukkan bahwa adanya hubungan antara sebelum dan sesudah dilakukan uji coba. Grafik 1 perbandingan rerata pada kelas kontrol dan kelas eksperimen.

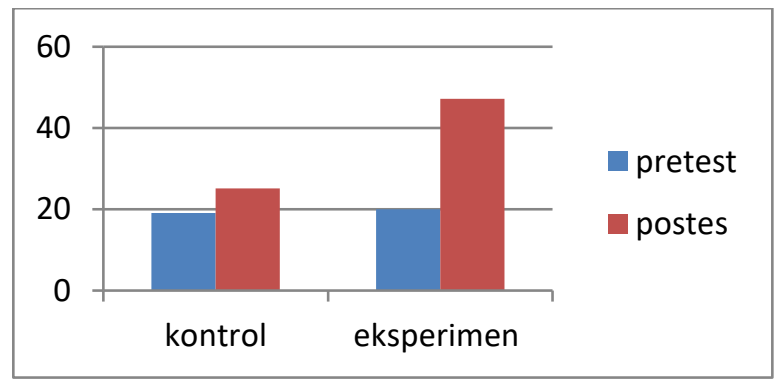

Gambar 1. Grafik perbandingan rerata kelas kontrol dan eksperimen.

Perkembangan Bahasa merupakan salah satu bidang pengembangan kemampuan dasar bagi pembentukan pengetahuan sesorang dalam peroses pembelajaran. oleh sebab pengembangan Bahasa anak di TK perlu distimulasi dengan berbagai cara. Hal ini sesuai dengan pendapat (Kemendiknas, 2010a) yang menjelaskan bahwa pelaksanaan pembelajaran pengembangan bahasa di TK dilakukan melalui kegiatan bercerita. Hal ini di dukung oleh (Bachri, 2005) bahwa bercerita merupakan sarana penyampaian pesan dengan penataan yang baik mulai dari judul cerita serta unsur-unsur lainnya yang membangun bercerita. (Hidayah, 2019) menjelaskan bercerita dapat digunakan sebagai alat bagi siswa untuk dapat menyatakan pendapat, gagasan, memberi informasi ataupun menerima informasi. (Elya et al., 2019) pada penelitiannya 
Dari validasi ahli dan uji coba yang dilakukan, dapat disimpulkan bahwa model BTPB yang dikembangkan telah memenuhi kriteria valid, praktis dan efektif sehingga dapat digunakan dalam pembelajaran. pengembangan model BPTB berpotensi memberikan inovasi dalam pembelajaran untuk anak usia 5-6 tahun (TK). Menurut Nieveen (2009) bahwa suatu produk dikatakan baik jika intervensi yang dilakukan memudahkan pengguna dengan cara yang sesui dengan kebutuhan penelitian maka produk dikatakan praktis. Efektifitas penelitian menunjukan model BPTB dapat mengembangkan pemahaman menyimak dan berbicara anak. Bercerita dapat meningkatkan daya simak anak dari apa yang didengarnya dari tuturan cerita guru seperti : tokoh cerita, karakter masing-masing tokoh, tokoh baik/kurang baik, alur cerita dan kesimpulan cerita. Hasil daya simak anak atas cerita gurunya dapat menstimulasi keterampilan berbicara anak sehingga mampu mengeluarkan perndapat, bertanya atau merespon situasi dan kondisi selama proses bercerita berlangsung dengan kalimat sederhana.

\section{SIMPULAN}

Studi lapangan menunjukkan beberapa kelemahan model yang digunakan guru, yaitu belum adanya teks cerita yang disesuaikan dengan tema, sintak pembelajaran bercerita yang dapat meningkatkan keterapilan berbahasa, interaksi sosial yang aka dibangun dalam pembelajaran. Model BTPB dirancang berdasarkan analisis awal yang ditemukan dilapangan, untuk menguji kelayakan maka dilakukan uji validitas oleh ahli dengan hasil sangat valid. Hasil uji coba menunjukkan perbedaan yang signifikan terhadap peningkatan perkembangan menyimak dan berbicara.

\section{UCAPAN TERIMA KASIH}

Terima kasih kami ucapkan kepada TK Adabiah, dan TK Mutiara Sari dan TK Adzkia sebagai tempat melakukan uji coba penelitian. Semoga Kerja sama ini tetap berlanjut dan bermanfaat bagi kedua belah pihak.

\section{DAFTAR PUSTAKA}

Agam, S. (2012). Peningkatan Perkembangan Bahasa Anak Melalui Bermain Peran Di Taman Kanak-Kanak. Taman Kanak Kanak, 1(1), 3-13. http://ejournal.unp.ac.id/index.php/paud/article/view/1600

Andriyani, R., Masrul, M., \& Fauziddin, M. (2018). Pengaruh Metode Becerita terhadap Kemampuan Kosakata Anak Usia Dini. Aulad: Journal on Early Childhood, 1(1), 18-27. https://doi.org/10.31004/aulad.v1i1.3

Anggraeni, D., Hartati, S., \& Nurani, Y. (2019). Implementasi Metode Bercerita dan Harga Diri dalam Meningkatkan Kemampuan Berbicara Anak Usia Dini. Jurnal Obsesi : Jurnal Pendidikan Anak Usia Dini, 3(2), 404. https:/ / doi.org/10.31004/obsesi.v3i2.224

Apriyanti, H. (2017). Pemahaman Guru Pendidikan Anak Usia Dini Terhadap Perencanaan Pembelajaran Tematik. Jurnal Obsesi: Jurnal Pendidikan Anak Usia Dini, 1(2), 111. https://doi.org/10.31004/obsesi.v1i2.22

Arlyanti, I., \& Apriliya, S. (2018). Pemilihan Bahan Ajar Cerita Anak berdasarkan Karakteristik Siswa SD. PEDADIDAKTIKA: Jurnal Ilmiah Pendidikan Guru Sekolah Dasar, 5(1), 221-231.

Bachri, B. S. (2005). Pengembangan kegiatan bercerita di taman kanak-kanak, teknik dan prosedurnya. Jakarta: Departemen Pendidikan Nasional.

Darmila, L., Hasibuan, H. B., \& Nunzairina. (2018). Perkembangan Kokakata Anak Usia. Jurnal Raudhah, 06(01), 1-8. http://jurnaltarbiyah.uinsu.ac.id/index.php/raudhah/article/download/276/271

Dra. Ni Wayan Suniasih, S. (2016). Penerapa Metode Bercerita Menggunakan Media Wayang Flanel untuk Meningkatkan Kemampuan Berbicara pada Anak. Jurnal Pendidikan Anak Usia Dini Undiksha, 4(2), 43-53. https:// doi.org/10.23887/ paud.v4i2.7618

Elena, B. dan L. j D. (1996). Tool of the mind. Upper Saddle River. 
Elya, M. H., Nadiroh, N., \& Nurani, Y. (2019). Pengaruh Metode Bercerita dan Gaya Belajar terhadap Kemampuan Berbicara Anak Usia Dini. Jurnal Obsesi : Jurnal Pendidikan Anak Usia Dini, 4(1), 312. https:// doi.org/10.31004/obsesi.v4i1.326

Fauziddin, M. (2017). Upaya Peningkatan Kemampuan Bahasa Anak Usia 4-5 Tahun melalui Kegiatan Menceritakan Kembali Isi Cerita di Kelompok Bermain Aisyiyah Gobah Kecamatan Tambang. Jurnal Obsesi: Jurnal Pendidikan Anak Usia Dini, 1(1), 42-51. https:// doi.org/10.31004/obsesi.v1i1.30

Fika, Y., Meilanie, S. M., \& Fridani, L. (2019). Peningkatan Kemampuan Bicara Anak melalui Bermain Peran Berbasis Budaya. Jurnal Obsesi : Jurnal Pendidikan Anak Usia Dini, 4(1), 50. https://doi.org/10.31004/obsesi.v4i1.229

Hartati, S. (2005). Perkembangan Belajar Anak Usia Dini. In Jakarta: Depdiknas. Dikti:Kemendikbud.

Hasriana Desti. (2014). Meningkatkan Kedisiplinan Melalui Metode Bercerita Pada Kelompok Bermain Di PAUD Amanah Kota LubukLinggau. Repository Universitas Bengkulu, 38.

Hidayah, S. N. (2019). Pengaruh Metode Bercerita Terhadap Perkembangan Bahasa Dan Karakter Anak Sekolah Dasar. https://doi.org/10.31227/osf.io/m3f9e

J.L, McBrien \& R.S, B. (1997). The language of learning: a guide to education terms. Choice Reviews Online, 35(04), 35-1912-35-1912. https:// doi.org/10.5860/choice.35-1912

Kemendiknas. (2010a). Kurikulum Taman Kanak-Kanak Pedoman Pengembangan Program Pembelajaran Di Taman Kanak-Kanak. Direktorat Pembinaan TK dan SD.

Kemendiknas. (2010b). Pedoman Pembelajaran Bidang Perkembangan Bahasa. Direktorat Pembinaan TK dan SD.

Kleain, R. \&. (2007). Design and development Reaserch. Lowrence Erlbaum Associate.Inc.

Kurniaman, O., \& Huda, M. N. (2018). Penerapan Strategi Bercerita Untuk Meningkatkan Keterampilan Menyimak Siswa Kelas III SD Muhamadiyah 6 Pekanbaru. Primary: $\begin{array}{lllll}\text { Jurnal Pendidikan Guru Sekolah Dasar, } & 249 .\end{array}$ https://doi.org/10.33578/jpfkip.v7i2.6284

Kusnilawati, K., Fauziddin, M., \& Astuti, A. (2018). Meningkatkan Aspek Perkembangan Nilai Agama dan Moral Anak Usia Dini dengan Penerapan Metode Bercerita Tema Islami. Aulad: Journal on Early Childhood, 1(1), 28-38. https:/ / doi.org/10.31004/aulad.v1i1.4

Moeslichatoen. (2006). Metode Pembelajaran di Taman Kanak-Kanak. Rieneka Cipta.

Nieveen, N. (2009). Formative evaluation in educational design research. An Introduction to Educational Design Research, 89-101.

Purwanto. (2010). Evaluasi Hasil Beljar. Pustaka Belajar.

Rosdiana, Y., Suratinah, Prakoso, T., Zuleha, Sugito, E., Santosa, P., \& Sutejo. (2011). Materi dan Pembelajaran Bahasa Indonesia SD. Universitas Terbuka.

Solehuddin. (2010). memfasilitasi perkembangan berfiki dan kreatif anak usia dini. Jurnal Pendidikan Indonesia.

Sonawat, R., \& Francis, J. M. (2007). Language Development For Preschool Children. Multi-Tech Publising.

Suharsiwi. (2000). Metodologi pembelajaran bahasa di TK. PT Darul Qolam.

Taja, N., Inten, D. N., \& Hakim, A. (2019). Upaya Meningkatkan Keterampilan Mengajar Baca Tulis Al-Qur`an bagi Guru. Jurnal Obsesi: Jurnal Pendidikan Anak Usia Dini, 3(1), 68. https:// doi.org/10.31004/obsesi.v3i1.135

Verika, T. (2015). Perencanaan Pembelajaran. Ilmu Tarbiyah "At-Tajdid, 5, 219-242.

Zuhdi, D. (1999). Pendidikan Bahasa dan. Sastra Indonesia di Kelas Tinggi. (Issue 3, pp. 1-8). depdikbud. 